\title{
Manipulation of Rumen Fermentation and Microbial Diversity for Live-Weight Gains of Sheep as Influenced by Ginger Powder and Lime Peel
}

\author{
M. I. Okoruwa and E. O. Aidelomon
}

\section{ABSTRACT}

The study was conducted to determine the influence of ginger powder and lime peel on manipulation of rumen function for live-weight gains of sheep. Twenty four West African dwarf sheep of about 8 - 9 months old with average weight of $7.00 \pm 0.95 \mathrm{~kg}$ were randomly assigned to four treatment diets in a completely randomized design. The prepared diets contained; ED1 $(0 \%$ ginger powder and $0 \%$ lime peel powder that served as control group), ED2 (0\% ginger powder and 3\% lime peel), ED3 (1.5\% ginger powder and $1.5 \%$ lime peel) and ED4 (3\% ginger powder and $0 \%$ lime peel). In all the diets examined, ED1 showed higher significant $(p<0.05)$ values in total fungi, Acetobact xylinum, Methanogens, total protozoa, Entodiniomorphs, Holotrichs, ammonia-nitrogen, total volatile fatty acids, acetate, butyrate and feed conversion ratio. However, total bacteria, Ruminococcus albus, Ruminococcus fibrisolvens, Bacillus spp, propionate, feed intake, nutrient digestibility, final and daily weight gains indicated significant $(p<0.05)$ higher values in diet ED3 than diets ED1, ED2 and ED4. Rumen pH was significantly $(\mathbf{p}<0.05)$ higher in ED4 as compared with other diets. There was no significant $(p>0.05)$ difference in Fibrobacter succinogens, iso-butyrate, valerate, iso-valerate and initial weight among diets. It can be concluded that using $1.5 \%$ ginger powder and $1.5 \%$ lime peel in the diets enhanced rumen fermentation and ecology for growth performance of sheep.

Keywords: growth, phytogenic-plants, rumen-function, sheep.
Published Online: October 22, 2020

ISSN: 2684-5199

DOI : 10.24018/ejbio.2020.1.5.98

\section{I. Okoruwa*}

Department of Animal Science, Ambrose Alli University, Nigeria. (e-mail: odionokos@yahoo.com, okosmich@gmail.com)

\section{E. O. Aidelomon}

Department of Animal Science, Ambrose Alli University, Nigeria.

*Corresponding Author

\section{INTRODUCTION}

Small ruminant production suffers insufficient feeds supply in the tropics, due to mainly low rain fall which can barely support natural pasture production in most years. This problem is further compounded by the competition between livestock and human feed industries for the available conventional feed ingredients. However, crop residues and agro by-products are considered as the most highly abundant and important available feed resources that are widely distributed at low cost with no competitive in their usage [1]. These feeds can be used to alleviate feed deficits and increase economic efficiency of feed production by reducing the pressure on cereal crops, particularly in regions where forages are scarce. Their high fiber content that is associated with low nutrient intake and digestibility limits their optimal utilization and productivity in ruminants [2], [3]. Thus, there is a strong incentive to search for natural feed additives with good potentials that can improve feed efficiency for enhancing ruminant performance. Recently, there has been much interest in the utilization of plant herbs or extracts as source of additives to aid digestion of poor quality feeds due to their secondary metabolites. Natural herbs are classified as phytogenic additives that have anti-microbial, anti-oxidant with anti-inflammatory substances that can improve immune system and stimulate digestive enzymes of animals for better productivity. [4] reported that phytogenic additives possess great potentials in rumen modulation for regulating micro-flora due to their several bioactive components such as flavonoids and phenolic compounds.

Ginger powder and lime peel are such natural additives that can act as antimicrobial, antioxidant, and bioflavonoids agents for improving poor quality feeds digestion, fight infection, reduce inflammation and eradicates toxic elements in grazing herbivores. They are locally available, and their products can be stored for longer periods without deterioration in nutritive and secondary components. Several authors [5], [6] and [7] have reported that ginger powder as additive in ruminant diets can modify overall rumen fermentation to inhibit methane production and increase rumen escapes of nutrients for more efficient enzymes digestion of protein and starch in the intestine. Notwithstanding, there has been limited research to date on the use of lime peel as a dependent potential substitute for antibiotics in sheep diets. Thus, the objective of the study was to assess the manipulation of rumen fermentation and microbial population for live weight gains of sheep as influenced by ginger powder and lime peel. 


\section{MATERIALS AND METHODS}

\section{A. Study Location}

The study was conducted at the sheep and goat unit of the livestock Teaching and Research Farm, Ambrose Alli University, Ekpoma, Nigeria. The location lies on longitude $6.09^{\circ} \mathrm{E}$ and latitude $6.42^{\circ} \mathrm{N}$ within the humid climatic zone of South-South Nigeria. It has an average annual rainfall and temperature of about $1556 \mathrm{~mm}$ and $31{ }^{\circ} \mathrm{C}$ respectively with relative humidity of about $78 \%$. The vegetation represents an interface of between the tropical rainforest and derived savannah.

\section{B. Experimental Diets}

Ginger root and lime peel were obtained within Ekpoma, cut into smaller surface area, air dried for five days before ginger was milled into powder form and lime peel was crushed into meal. Thereafter, they were incorporated into the supplementary diets at different and equal proportions (Table, 1). Guinea grass was cut at a re-growth age of between 7 and 8 weeks, allowed to wilt overnight and chopped into smaller sizes. However, guinea grass and supplementary diets were used in a ration of 60:40 in form of total mixed ration. The four prepared diets contained; $\mathrm{ED}_{1}$ (ginger powder $0 \%$ and lime peel powder $0 \%$ as control group), $\mathrm{ED}_{2}$ (ginger powder $0 \%$ and lime peel $3 \%$ ), $\mathrm{ED}_{3}$ (ginger powder $1.5 \%$ and lime peel $1.5 \%$ ) and $\mathrm{ED}_{4}$ (ginger powder $3 \%$ and lime peel $0 \%$ ).

TABLE 1: GROSS COMPOSITION (\%) OF SUPPLEMENTARY DIETS

\begin{tabular}{lcccc}
\hline \multirow{2}{*}{ Ingredients } & \multicolumn{4}{c}{ Experimental Diets } \\
\cline { 2 - 5 } & $\mathrm{ED}_{1}$ & $\mathrm{ED}_{2}$ & $\mathrm{ED}_{3}$ & $\mathrm{ED}_{4}$ \\
\hline Wheat offal & 40.00 & 37.00 & 37.00 & 37.00 \\
$\begin{array}{l}\text { African star apple } \\
\text { pulp/peel }\end{array}$ & 27.00 & 29.00 & 31.00 & 33.00 \\
Dried brewers grain & 24.00 & 22.00 & 20.00 & 18.00 \\
Groundnut husk & 5.00 & 5.00 & 5.00 & 5.00 \\
Ginger powder & - & - & 1.50 & 3.00 \\
Lime peel & - & 3.00 & 1.50 & - \\
Bone meal & 2.50 & 2.50 & 2.50 & 2.50 \\
Vitamin premix & 1.00 & 1.00 & 1.00 & 1.00 \\
Salt & 0.50 & 0.50 & 0.50 & 0.50 \\
Total & 100.00 & 100.00 & 100.00 & 100.00 \\
\hline
\end{tabular}

\section{Animals, Design and Management}

Twenty four West African dwarf male sheep of about 89 months old with initial average live weight of $7.00 \pm 0.95 \mathrm{~kg}$ were used for the study. They were quarantined and placed on prophylactic treatments for two weeks during which they were also subjected to control of external and internal parasites.

At the end of the adaption period, the sheep were randomly allocated to the four dietary treatments that were replicated three times with two sheep per replicate in a completely randomized design. The sheep were housed adjacent to each other in individual semi-open pens with feeders and water troughs available. They were offered feeds twice daily at about 8:00am and 4:00pm prompt. The quantity of the diet offered to each sheep was calculated on the basis of $5 \%$ dry matter of their body weight. The amount of feed given was adjusted every week according to live weight change. The sheep had free access to drinking water and the experiment lasted for 90 days exclusive of the two weeks adaptation period.

\section{Intake and Live-Weight Change}

Diets offered and leftover were measured for individual animals daily in the morning prior to feeding to compute the feed intake. Animals were weighed at the commencement of the study before giving the experimental diets, subsequently on weekly basis to estimate live-weight changes for the individual animals.

\section{E. Digestibility}

At the end of growth study four sheep per treatment were selected and transferred into individual metabolic cages made for separate collection of faeces and urine. They were acclimatized for the first 7 days, before another 7 days collection of faeces voided per sheep daily. The collected faecal samples for each sheep was bulked, properly mixed and about $10 \%$ sub-sample was pooled and kept in the freezer $(-20 \%)$ for laboratory analysis. Thus, nutrient digestibility was calculated by standard procedures reported by [8].

\section{F. Rumen Fermentation and Ecology}

Fore-stomach sampling was preceded once weekly during the feeding trial of the sheep. About $100 \mathrm{ml}$ of rumen liquor samples were collected from each sheep using oral stomach tube and inserted through the oesophagus approximately 3 hours after the incoming morning feeding. The fluid was monitored visually to ensure that they were not polluted with saliva. Rumen $\mathrm{pH}$ of the fluid was measured immediately after sampling using a portable digital pH meter (Mettler-Toledo Ltd, England). However, the liquor was squeezed through four layers of cheese-cloth to remove the feed coarse particles. The filtered liquor was divided into fractions for the determination of rumen fermentation and microbes. Sub-samples of $10 \mathrm{ml}$ were acidified with a $1 \mathrm{~m}$ sulphuric acid solution to measure ammonia nitrogen $\left(\mathrm{NH}_{3}-\mathrm{N}\right)$ concentration and total volatile fatty acid (VFA) as previously reported by [9]. Another $10 \mathrm{ml} \mathrm{sub}$-samples were treated with $2 \mathrm{ml}$ of $25 \%$ meta-phosphoric acid (prepared $5 \mathrm{~N}$ sulphuric acid) kept overnight at $4{ }^{\circ} \mathrm{C}$ and centrifuged at $584 \mathrm{rpm}$ for $15 \mathrm{~min}$ to measure individual volatile fatty acids using gas chromatography according to the procedures reported by [2].

The other fraction of the rumen liquor was used for fungi and protozoa counts with preparation of bacteria culture before counting. Six strains of cellulolytic bacteria were isolated from rumen fluid and were grown in a purely cultural. The indentified and separated strains were Ruminococcus albus, Ruminococcus fibrisolvens, Bacillus spp, Fibrobacter succinogens, Acetobact xylinum and Methanogens. Pour-plate technique for pure preparation of cultures, according to [10] was used for the isolation of species. The samples were immediately gassed with carbondioxide viable counts of rumen cellulolytic bacteria and their classification were done as reported by [11] and [12] respectively. About $20 \mathrm{ml}$ of the rumen fluid were also stored in $40 \mathrm{ml}$ of $10 \%$ formal saline for direct counts of 
fungi (Correddu et al. 2019). However, counting of protozoa was divided into Entodiniomorphs and Holotrichs. One $\mathrm{ml}$ of the filtered rumen fluid was added to four $\mathrm{ml}$ of methyl green-formalin-saline solution for the counting. The number of protozoa was microscopically (100x) counted in a drop of rumen liquor with the defined volume with the division on the Entodiniomorphs and Holotricha groups as noted by El-Essawy (2019). Measurements were done in duplicate from each sample and the average of these measurements was used to estimated the number of protozoa present in the initial sample.

\section{G. Chemical and Statistical Analyses}

Feed samples were dried for 48 hours at $60{ }^{\circ} \mathrm{C}$ in a forced - air oven to determine the dry matter (DM) content before ground in a wiley mill to pass through a $1 \mathrm{~mm}$ sieve for proximate and phyto-chemicals composition according to the method described by AOAC (1990).

Data obtained from the study were subjected to analysis of variance (ANOVA) using the general linear model (GLM) procedures. Where significant difference between treatment effects occurred, means were separated by Duncan multiple range test [14]. The mathematical model used for the analysis is as follows:

$$
Y i j=G+A i+e i j k
$$

where

Yijk = independent variable (live-weight gain, rumen fermentation.........).

$\mathrm{G}=$ overall mean of the observed variable.

$\mathrm{Ai}=$ effect due to $\mathrm{i}^{\text {th }}$ treatment diets.

eijk $=$ effect of random residual error.

\section{RESULTS}

In the three feed ingredients examined (Table 2), guinea grass (GG) recorded the highest content of crude protein and crude fibre but relatively lower in dry matter and nitrogen free extract values as compared with ginger powder (GP) and lime peel (LP). However, LP marked higher values in ether extract and ash than the values obtained in GP and LP. Notwithstanding, supplementary diets were varied according to the type and amount of feed ingredients used in the diets. The test diets had relatively higher dry matter, crude fiber and nitrogen free extract than the control diet. Generally, similar values were showed for crude protein, ether extract and ash with no remarkable difference among treatment diets. Phyto-chemical components had highest contents in GP, LP and test diets than GG and control diet as shown in Table 2.

TABLE 2: PROXIMATE AND PHYTO-CHEMICAL COMPOSITION (\%DM) OF GINGER POWDER, LIME PEEL AND EXPERIMENTAL DIETS

\begin{tabular}{|c|c|c|c|c|c|c|c|}
\hline & \multicolumn{3}{|c|}{ Feed Ingredients } & \multicolumn{4}{|c|}{ Supplementary Diets } \\
\hline & GG & GP & LP & $\mathrm{ED}_{1}$ & $\mathrm{ED}_{2}$ & $\mathrm{ED}_{3}$ & $\mathrm{ED}_{4}$ \\
\hline Dry matter & 86.98 & 89.69 & 88.48 & 89.37 & 92.44 & 96.92 & 98.46 \\
\hline Crude protein & 8.75 & 7.52 & 4.24 & 12.91 & 12.62 & 12.28 & 12.04 \\
\hline Ether extract & 2.98 & 5.47 & 8.05 & 4.22 & 4.02 & 4.11 & 3.96 \\
\hline Crude fibre & 30.09 & $10 . .38$ & 21.69 & 17.99 & 19.07 & 19.58 & 20.02 \\
\hline Ash & 5.79 & 6.89 & 9.87 & 6.02 & 5.42 & 5.63 & 5.85 \\
\hline Nitrogen free extract & 40.47 & 58.43 & 42.63 & 43.86 & 52.32 & 55.48 & 56.60 \\
\hline \multicolumn{8}{|c|}{ Phyto-chemical components } \\
\hline Tannin & 0.81 & 3.42 & 1.98 & 0.06 & 0.42 & 0.82 & 0.99 \\
\hline Saponin & 1.07 & 0.75 & 0.02 & 0.01 & 0.07 & 0.27 & 0.38 \\
\hline Alkaliod & 0.04 & 10.11 & 6.86 & 0.31 & 0.58 & 0.79 & 1.03 \\
\hline Steroid & $0-01$ & 0.04 & 0.21 & 0.01 & 0.03 & 0.09 & 0.17 \\
\hline Flavonoid & 0.02 & 5.46 & 3.79 & 0.03 & 0.29 & 0.47 & 0.73 \\
\hline
\end{tabular}

$\mathrm{GG}=$ Guinea grass, GP = Ginger powder, $\mathrm{LP}=$ Lime peel.

There were differences in the distribution of rumen microbial community (Table, 3 ) in sheep as influenced by inclusion of feed additives in diets. The levels of total fungi, cellulytic bacteria diversity of Acetobact xylinum and Methanogens in the rumen fluid were significantly decreased $(\mathrm{P}<0.05)$ in counts as ginger powder and lime peel were added in the diets. On the other hand, their effects as additives showed extremely significant $(\mathrm{P}<0.05)$ higher values for total bacteria, Ruminococcus albus, Ruminococcus fibrisolvens and Bacillus spp as compared with control diet. However, Fibrobacter succinogens diversity indices observed in the study had no significant $(\mathrm{P}>0.05)$ difference irrespective of the additives included in the diets. Interestingly, higher significant $(\mathrm{P}<0.05)$ abundance spices of total protozoa, holotrich and entodiniomorphs were found in control diet than the test diets.

The use of natural feed additives in the study showed no significant $(\mathrm{P}>0.05)$ effects in values recorded for isobutyrate, valerate and iso-valerate among diets (Table,4). However, remarkable differences were observed in the rate of ammonia nitrogen, total volatile fatty acids, and acetate with butyrate production in the rumen fluid of sheep. It was avidly noticed that diet with no additives had significant $(\mathrm{P}<0.05)$ greater values than those with additives in their diets. The rumen $\mathrm{pH}$ and molar proportion of propionate were significantly $(\mathrm{P}<0.05)$ higher in diets with mixture of ginger and lime or solely ginger or lime inclusion than the control diet.

Feed intake, apparent digestibility and live weight change of sheep were significantly $(\mathrm{P}<0.05)$ influenced by feed additives in the diets except initial live weight that was not significantly $(\mathrm{P}>0.05)$ affected (Table 5). Total daily feed intake, digestibility of dry matter and crude protein were found to register higher values in test diets than the control group. Similarly, digestibility coefficient of crude fibre appeared to be higher in diet $\mathrm{ED}_{3}$ followed by $\mathrm{ED}_{4}$ and $\mathrm{ED}_{2}$ but considerably lower in control diet $\mathrm{ED}_{1}$. Higher values of final live weight and weight gains of sheep were recorded for diets $\mathrm{ED}_{2}, \mathrm{ED}_{3}$ and $\mathrm{ED}_{4}$ as compared with diet $\mathrm{ED}_{1}$ that had extremely lower values. However, feed conversion ratio 
European Journal of Biology and Biotechnology www.ejbio.org

was more pronounced in control diets than the test diets in terms of mean values.

TABLE 3: MEAN VALUES FOR RUMEN MICROBIAL POPULATION (X106CFM/ML) OF SHEEP FED EXPERIMENTAL DIETS

\begin{tabular}{|c|c|c|c|c|c|}
\hline \multirow{2}{*}{ Parameters } & \multicolumn{4}{|c|}{ Experimental Diets } & \multirow{2}{*}{$\mathrm{SEM} \pm$} \\
\hline & $\mathrm{ED}_{1}$ & $\mathrm{ED}_{2}$ & $\mathrm{ED}_{3}$ & $\mathrm{ED}_{4}$ & \\
\hline Total fungi $\times 10^{4}$ & $5.86^{\mathrm{a}}$ & $4.16^{\mathrm{b}}$ & $4.72^{\mathrm{b}}$ & $4.23^{\mathrm{b}}$ & 0.52 \\
\hline Total bacteria $\times 10^{4}$ & $5.09^{\mathrm{b}}$ & $7.99^{\mathrm{a}}$ & $8-67^{\mathrm{a}}$ & $8.39^{\mathrm{a}}$ & 0.48 \\
\hline Ruminococcus albus & $3.76^{\mathrm{b}}$ & $4.98^{\mathrm{a}}$ & $5.29^{\mathrm{a}}$ & $5.04^{\mathrm{a}}$ & 0.32 \\
\hline Ruminococcus fibrisolvens & $3.79^{c}$ & $4.89^{\mathrm{b}}$ & $6.09^{\mathrm{a}}$ & $5.98^{\mathrm{a}}$ & 0.79 \\
\hline Fibrobacter succinogens & 5.01 & 5.13 & 5.27 & 5.36 & 0.33 \\
\hline Bacillus spp & $2.21^{\mathrm{c}}$ & $4.28^{b}$ & $5.75^{\mathrm{a}}$ & $4.59^{b}$ & 0.65 \\
\hline Acetobact xylinum & $3.84^{\mathrm{a}}$ & $2.96^{\mathrm{b}}$ & $2.31^{\mathrm{b}}$ & $2.72^{\mathrm{b}}$ & 0.32 \\
\hline Methanogens & $4.08^{\mathrm{a}}$ & $2.01^{\mathrm{b}}$ & $1.34^{\mathrm{c}}$ & $1.60^{\mathrm{c}}$ & 0.15 \\
\hline Total protozoa $\times 10^{4}$ & $8.72 \mathrm{a}$ & $3.46^{\mathrm{b}}$ & $2.49^{c}$ & $2.85^{\mathrm{c}}$ & 0.03 \\
\hline Holotrich & $5.03^{\mathrm{a}}$ & $2.10^{\mathrm{b}}$ & $1.41^{\mathrm{c}}$ & $1.52^{\mathrm{c}}$ & 0.02 \\
\hline Entodiniomorphs & $3.69^{\mathrm{a}}$ & $1.36^{\mathrm{b}}$ & $1.08^{\mathrm{b}}$ & $1.33^{\mathrm{b}}$ & 0.13 \\
\hline
\end{tabular}

${ }^{a, b, c}$ Means in the same row with varying superscript differ significantly $(\mathrm{P}<0.05)$.

TABLE 4: MEAN VALUES FOR RUMEN FERMENTATION PROFILE OF SHEEP FED EXPERIMENTAL DIETS

\begin{tabular}{|c|c|c|c|c|c|}
\hline \multirow[t]{2}{*}{ Parameters } & \multicolumn{4}{|c|}{ Experimental Diets } & \multirow[b]{2}{*}{$\mathrm{SEM} \pm$} \\
\hline & $\mathrm{ED}_{1}$ & $\mathrm{ED}_{2}$ & $\mathrm{ED}_{3}$ & $\mathrm{ED}_{4}$ & \\
\hline Rumen $\mathrm{pH}$ & $6.12^{\mathrm{b}}$ & $6.77^{\mathrm{a}}$ & $6.79^{\mathrm{a}}$ & $6.81^{\mathrm{a}}$ & 0.32 \\
\hline $\mathrm{NH}_{3}-\mathrm{N}(\mathrm{mg} / \mathrm{dl})$ & $9.06^{\mathrm{a}}$ & $5.72^{\mathrm{b}}$ & $4.95^{\mathrm{c}}$ & $5.68^{\mathrm{b}}$ & 0.21 \\
\hline Total VFAs (mM) & $86.75^{\mathrm{a}}$ & $68.04^{b}$ & $60.49^{c}$ & $64.03^{\mathrm{c}}$ & 0.82 \\
\hline Acetate $(\mathrm{mol} / 100 \mathrm{ml})$ & $64.07^{\mathrm{a}}$ & $50.92^{\mathrm{b}}$ & $46.94^{\mathrm{c}}$ & $48.78^{c}$ & 0.75 \\
\hline Propionate (mol/100ml) & $16.72^{\mathrm{c}}$ & $24.78^{\mathrm{b}}$ & $28.27^{\mathrm{a}}$ & $26.94^{\mathrm{a}}$ & 0.37 \\
\hline Butyrate (mol/100ml) & $5.21^{\mathrm{a}}$ & $2.62^{\mathrm{b}}$ & $2.15^{\mathrm{b}}$ & $2.43^{\mathrm{b}}$ & 0.10 \\
\hline Iso-butyrate $(\mathrm{mol} / 100 \mathrm{ml})$ & $2 . .16$ & 2.14 & 2.09 & 2.07 & 0.02 \\
\hline Valerate $(\mathrm{mol} / 100 \mathrm{ml})$ & $1 . .71$ & 1.57 & 1.50 & 1.39 & 0.04 \\
\hline Iso-valerate (mol/100ml) & 0.98 & 0.93 & 0.95 & 0.94 & 0.06 \\
\hline
\end{tabular}

a,b,c Means in the same row with varying superscript differ significantly $(\mathrm{P}<0.05)$.

$\mathrm{NH}_{3}-\mathrm{N}=$ Ammonia nitrogen, VFAs = Volatile fatty acids.

TABLE 5: MEAN VALUES FOR FEED INTAKE, DIGESTIBILITY AND LIVE WEIGHT CHANGE OF SHEEP FED DIETS SUPPLEMENTED WITH GINGER POWDER AND LIME PEEL OR THEIR COMBINATION

\begin{tabular}{|c|c|c|c|c|c|}
\hline \multirow{2}{*}{ Parameters } & \multicolumn{4}{|c|}{ Experimental Diets } & \multirow{2}{*}{$\mathrm{SEM} \pm$} \\
\hline & $\mathrm{ED}_{1}$ & $\mathrm{ED}_{2}$ & $\mathrm{ED}_{3}$ & $\mathrm{ED}_{4}$ & \\
\hline Feed intake, $\mathrm{g} / \mathrm{d}$ & $301.98^{\mathrm{c}}$ & $311.72^{b}$ & $323.62^{\mathrm{a}}$ & $318.22^{b}$ & 1.06 \\
\hline \multicolumn{6}{|l|}{ Digestibility (\%) } \\
\hline Dry matter & $64,35^{\mathrm{b}}$ & $70.86^{\mathrm{a}}$ & $72.05^{\mathrm{a}}$ & $71.58^{\mathrm{a}}$ & 0.75 \\
\hline Crude protein & $60.35^{\mathrm{b}}$ & $71.63^{\mathrm{a}}$ & $74.87^{\mathrm{a}}$ & $72.96^{\mathrm{a}}$ & 0.92 \\
\hline Crude fibre & $58.06^{\mathrm{c}}$ & $61.75^{\mathrm{b}}$ & $66.32^{\mathrm{a}}$ & $63.22^{\mathrm{b}}$ & 0.88 \\
\hline \multicolumn{6}{|l|}{ Live weight $(\mathrm{kg})$} \\
\hline Initial & 8.00 & 7.97 & 7.89 & 7.93 & 0.16 \\
\hline Final & $10.49^{\mathrm{b}}$ & $10.99^{\mathrm{b}}$ & $11.75^{\mathrm{a}}$ & $11.28^{\mathrm{a}}$ & 0.43 \\
\hline Total weight gain & $2.49^{\mathrm{b}}$ & $3.02^{\mathrm{a}}$ & $3.86^{\mathrm{a}}$ & $3.35^{\mathrm{a}}$ & 0.05 \\
\hline Live weight gain g/d & $32.76^{\mathrm{c}}$ & $39.74^{\mathrm{a}}$ & $50.79^{\mathrm{a}}$ & $44.08^{b}$ & 0.59 \\
\hline Feed conversion ratio & $9.22^{\mathrm{a}}$ & $7.84^{\mathrm{b}}$ & $6.37^{\mathrm{c}}$ & $7.24^{\mathrm{b}}$ & 0.62 \\
\hline
\end{tabular}

a,b,c Means in the same row with varying superscript differ significantly $(\mathrm{P}<0.05)$.

\section{DISCUSSION}

Herb plants are phytogenic in nature as they contain secondary metabolites and anti-microbial properties that improve health benefits and modify rumen fermentation to stimulate digestion in ruminants [15], [16]. When use as additives in livestock feeds, they can increase appetite and feed utilization efficiency to optimize performance [5]. The phyto-chemical components of ginger powder (GP) observed in this study was higher than the recorded values in lime peel (LP). However, their tannin levels were considered low and safe with regards to tannin poisoning critical values of $7.3-9.0 \mathrm{mg} / \mathrm{g}$ reported by [6].

Nutrient contents obtained in guinea grass, GP and LP were comparable with the range values reported in literature by [16] and [7] respectively. Variations registered in nutrient composition of experimental diets were reflection of different feed ingredients used in the diets. It is important 
to note that the formulated diets crude protein values observed in the treatments were above $8 \%$ crude protein minimum value required for small ruminants' performance in the tropics [17].

The influences of ginger powder or lime peel and their mixture in diets were effective in reducing total fungi, Acetobact xylinum and Methanogens population in sheep. This could probably because of their phyto-chemical and poly-phenol components that were not appropriate for their thrived, hence affected their production. Feeding additives that are rich in secondary metabolites had been reported to reduce methane emission directly by inhibition of Methanogens and indirectly by reduction of fiber digestion fungi in the rumen [18]. Thus, the higher diversity of cellulolytic bacteria of Ruminococcus albus, Ruminococcus fibrisolvens and Bacillus spp in the test diets indicates that the additives used were the main contributors for their increased in production. This evidences demonstrated the effects of bioactive compounds in the diets which likely be the mechanism encouraging the increase of their outflow as bacteria spices that improved the utilities fermentation as part of digestive process and supply of energy to the host animal. Some researchers have proved that flavonoid in herb plants can improve the levels of Ruminococcus albus and the diversity of Ruminococcus fibrisolvens with Bacillus spp in the rumen of cows without any negative effect on their fermentation [4], [19]. Fibrobacter succinogens appeared to be dominant species in the study irrespective of the diets. The reason could be traced to their ability to tolerate moderate concentration of the secondary compounds in the diets. However, ciliate protozoa are important in ruminants but not essential in the rumen ecosystem and to the well-being of the host animals. They account for about half of the total microbial biomass in the rumen with $50 \%$ of the total fermentation products which make them a significant hydrogen producer that encourage methane emissions [20]. Their presences in rumen degrade dietary protein for production of ammonia nitrogen concentration. They also engulf bacteria for their amino acid requirement in the rumen ecosystem. Notwithstanding, the reduction of protozoa (defaunation) in the rumen of sheep on diets with additives in this current study might translated to the decrease in endo-symbiotic methanogens with low hydrogen availability that could led to reduction in energy wastage from digestion of grass cell walls. Perhaps positive effect of eliminating methanogens that existing as endo and ecto-symbiotic with ciliate protozoa in the rumen of sheep have been reported by [21] to increase ruminant average weight gain by $9 \%$ and reduced entric methane emission by $11 \%$.

Fibre and starch digesting microbes thrive well at rumen $\mathrm{pH}$ of 6.0 to 6.8 and 5.5 to 6.0 respectively, with their balance level occurring at rumen $\mathrm{pH}$ of 6.0. Several authors [22], [23] have considered a rumen $\mathrm{pH}$ greater than 5.9 to be normal for fibre digestion. However, the rumen $\mathrm{pH}(6.12$ to 6.83) of sheep obtained in this study were within the optimal normal range considered for microbial digestion activity but higher than the $\mathrm{pH}$ of 5.6 and 5.8 levels suggested to be marginal for developing problem of acidosis [23]. The decreased of ammonia nitrogen concentration in diets with ginger and lime peel or their mixture inclusion were consequence of defaunation and decreased degradability of protein feed that increased bacteria biomass in the rumen. It is noteworthy that, this could be an advantage to the sheep as it associated with greater rumen escape of microbial protein out flows into the duodenum which translated to higher supply of protein for efficient digestibility observed in sheep. This is in line with the report of [24] who observed that tannin component in herb plants can form complexes with protein and protect it from degradation in the rumen which eventually flows and dissociated under the acid condition of the abomasums and in turns leading to better digestion of protein in host animals, especially when feed is deficient in protein rather than energy content.

The strong correlation between defaunation and methanogens counts observed in the test diets had no negative impact on rumen fermentation and degradability but resulted in modulating rumen digestion of grass cell and starch feeds which were considered to be the two sources of energy supply for the host sheep. However, the beneficial effect of this valuable reason was seen in greater proportion of propionate and decreased fractions of acetate with butyrate in the rumen, leading to low rate of total volatile fatty acids production. This scenario could responsible for the decreased in the digestibility of fibre components in control diet. This is excepted as the connection between higher molar propionate with low fraction of acetate improved feed intake, digestibility and weight gains in sheep on test diets (Table, 5). It could also be relatively linked to the increase in rumen $\mathrm{pH}$ of sheep on test diets which was earlier stated by [25] as mechanism that may likely decreased the incidence of metabolic disorder such as acidosis in ruminants. This is implicated in recent review of [21] who found that decrease in acetate and butyrate will reduce methane emission to release hydrogen for incorporation into propionate acids that is the main precursor of glucose synthesis for efficient energy production require for metabolism and absorption in ruminants.

\section{CONCLUSIONS AND RECOMMENDATION}

The study discovered that, influence of ginger powder and lime peel in the diets of sheep did not show any adverse effect on rumen function but leads to variation in rumen ecology which affected the fermentation pattern and performance of sheep positively. These changes mostly reduced methanogens, protozoa numbers, acetate and butyrate with increased in propionate proportion. These positive results promoted feed intake and digestibility of nutrients which translated to better weight gains of sheep.

However, this enhancement that occurred in test diets was more efficient in diet that contained mixture of ginger powder $1.5 \%$ and lime peel $1.5 \%\left(\mathrm{ED}_{3}\right)$ than diet with either ginger powder or lime peel. Furthermore, long-term experiment is required in this study to determine the production benefits of using mixture of ginger powder and lime peel in the diets of sheep. 


\section{REFERENCES}

[1] Okoruwa, M. I. 2020. The effect of feeding leguminous tree foliages on performance of goats fed basal diets of grass and crop residues. Livestock Research for Rural Development. http://www.lrrd.org.lrrd32/07/odion200526.html.

[2] Mor, P., Bals, B., Kumar, S., Tyagi, N., Reen, J. K., Tyagi, B., Choudhury, P. K., Pyagi, A. K. 2019. Influence of replacing concentrate mixture with AFEX pellets on rumen fermentation, blood profile and acetamide content in the rumen of crossbred (Alpine $\mathrm{x}$ Beetle) female goats. Small Ruminant Research, 170: 109 - 115.

[3] Fadiyimu, A. A., Alokan, J. A., Fajemisin, A. N., Onibi, G. E. 2016. Feed intake, growth performance and carcass characteristics of West African dwarf sheep fed Moringa oleifera, Gliricidia sepium or cassava fodder as supplements to Panicum maximum. Journal of Experimental Agriculture International, 14 (4); 1-10.

[4] Li, Y., Zhang, G., Xu, H., Zhou, S., Dou, X., Lin, C., Zhang, X., Zhao, H., Zhang, Y. K. 2019. Effects of replacing alfalfa hay with Moringa oleifera leaves and peduncles on intake, digestibility and rumen fermentation in dairy cows. Livestock Science, 220: 211-216.

[5] Al-Azazi, A. S. H., Baraka, T. A., Khalaf, A. M. 2018. Effect of ginger powder (Zingiber officinale) on selected rumen and blood serum constituents in sheep. Indian Journal of Applied Research, 8(4): $450-457$.

[6] Aletor, O. 2014. Physiochemical characterisation and antioxidant properties of the seeds and oils of ginger (Zingiber officinal) and garlic (Allium sativum). Science Journal of chemistry 2(6); 44-50.

[7] Mathew, B. B., Jatawa, S. K., Tiwari, A. 2012. Phytochemical analysis of citrus limonum pulp and peel. Internatioal Journal of Pharmacy and pharmaceutical Science, 4(2); 269-371.

[8] McDonald, P., Edward, R. A., Greenhalgh, I. F. D. 1987. Animal Nutrition. $8^{\text {th }}$ Edition. Longman Group (FE) Ltd. Hongkong.

[9] Correddu, F., Nudda, A., Battacome, G., Boe, R., Francesconi, A. H. D., Pulna, G. 2015. Effects of grape seedsupplementation, alone or association with linseed in ruminal metabolism in Sards dairy sheep. Animal Feed Science Technology, 199, 61 - 72.

[10] ATCC. 1992. American Type Culture Collection Catalogue and Bacterophages $\left(18^{\text {th }} \mathrm{Ed}\right)$. USA.

[11] Correddu, F., Fancello, F., Chessa, L., Atzori, A. Z., Pulina, G., Nudda, A. 2019. Effects of supplementation with exhausted myrtle barriers on rumen function of dairy sheep. Small Ruminant Research, $170,51-61$.

[12] El-Essawy, M. A. 2019. Effect of lipid source; linseed or soybean in diets on rumen and blood fatty acids profiles in Damascus goats. Australian Journal of Basic and Applied Sciences, 13 (5): 1-10.

[13] AOAC. 1990. Official Methods of Analysis. Association of official analytical chemist, $15^{\text {th }}$ Edition (Khelrick, editor) Arlington pp 1230.

[14] SAS. 2009. User's Guide: version 9.2. Statistical Analysis System (SAS) Institutres Inc. Cary, NC, USA.

[15] Kongmun, P., Wanapat, M., Pakdee, P., Navanukra, Yu, Z. 2011. Manipulation of rumen fermentation and ecology of swamp buffalo by coconut oil and garlic powder supplementation. Livestock Science, $135,84-92$.

[16] Soroor, M. E. N., Moeini, M. M. 2015. The influence of ginger (Zinger officinale) on in-vitro rumen fermentation patterns. Annual Research and Review in Biology, 5(1): $54-63$.

[17] Norton, B. W. 2003. Tree legumes and dietary supplements. In: forage tree legumes in tropical agriculture. Gutteridge, R. C. and Shelton (Ed) CAB International Walling-ford Oxon, Pp $192-201$.

[18] Zulfa, I. H., Bachruddin, Z., Kumiawati, A. 2019. Effects of lemon grass leaves as essential oil sources on rumen microbial ecology and nutrient digestibility in an in-vitro system. Pakistan Journal of Nutrition, 18: $254-259$.

[19] Hart, K. J., Yanez-Ruiz, D. R., Duval, S. M. McEwan, N. R., Newbold, C. J. 2008. Plant extract to manipulate rumen fermentation. Animal Feed Science and Technology, 147: 8-35.

[20] Newbold, C. J., Fuente G, Belanche A, Ramos-morales, E., McEwan, N. 2015. The role of ciliate protozoa in the rumen. Frontiers in Microbiology 6; 1-14.

[21] Nguyen, S. N., Thi Nguyen, H. D., Hegarty R. S. 2020. Defaunation and its impacts on ruminal fermentation, entric methane production and animal productivity. Livestock Research for Rural Development. http://www.lrrd.org.lrrd32/04/.html.

[22] Patra, A. K. 2011. Effects of essential oils on rumen fermentation, microbial ecology and ruminant production. Asian Journal of Animal and Veterinary Advances, 6; $416-428$.

[23] Karimizadeh, E., Chaji, M., Mohammadabadi, T. 2017. Effects of physical form of diet on nutrient digestibility, rumen fermentation, rumination, growth performance and protozoa population of finishing lambs. Animal Nutrition 3,139-144.
[24] Nguyen, S. N., Hegarty, R. S. 2019. Distribution of ciliate protozoa population in the rumen, reticulum and omasum of angus heifers offered lucerne cereal mix. Livestock Research for Rural Development. http://www.lrrd.org.lrrd31/09nhson31146/.html.

[25] Wallace, R. J., McEwan, N. R., McInotoch, F. M., Teferedegne, B., Newbold, C. J. 2002. National products as manipulators of rumen fermentation. Asian-Australasian Journal of Animal Science, 10: $1458-1468$. 